\title{
Effect of setting on the gelling properties of a protein concentrate from giant squid (Dosidicus gigas) mantle
}

\author{
Miriam Fernanda ESCALANTE-RODRÍGUEZ, Claudia Lizeth MURRIETA-MARTÍNEZ², \\ Victor Manuel OCAÑO-HIGUERA ${ }^{1}$, Benjamín RAMÍREZ-WONG², Saúl RUIZ-CRUZ³, \\ Guillermo RODRÍGUEZ-OLIBARRIA², Enrique MARQUEZ-RIOS ${ }^{2 *}$
}

\begin{abstract}
Different studies on obtaining protein concentrates or surimi from giant squid (Dosidicus gigas) have reported that soft gels are obtained in comparison with other fish species. Therefore, the aim of this research was to investigate the effect of the setting (30 and $60{ }^{\circ} \mathrm{C}$, for $0,30,60$, and $90 \mathrm{~min}$ ) on the gelling capacity as a possible alternative to improve the textural characteristics of the gels. Treatments at $60{ }^{\circ} \mathrm{C}(\mathrm{G} 4, \mathrm{G} 5$, and G6) had a higher percentage of insoluble protein, while the electrophoretic profile showed the presence of high molecular weight (HMW) aggregates, as well as the decrease of myosin, paramyosin and actin bands as the incubation time was increased. Likewise, these systems presented a lower content of total sulfhydryl (TSH), which is attributed to the formation of disulfide bridges. The texture profile analysis (TPA) showed that the setting application affected the different parameters evaluated (strength, elasticity, and cohesiveness). Setting as pretreatment did not prove to be a good alternative for the gelling of proteins from giant squid mantle, since the control treatment (no setting) was that which exhibited better textural characteristics.
\end{abstract}

Keywords: squid; gelling; setting.

Practical Application: The setting phenomenon was not a good option to improve the gelling capacity of giant squid proteins.

\section{Introduction}

Giant squid (Dosidicus gigas) is one of the most abundant and large squid species found in the pelagic zone of the eastern Pacific, from Chile to the Oregon coasts (Nigmatullin et al., 2008). The commercial appeal of this species lies in its great abundance, low cost, and high yield, because a yield of $75 \%$ can be obtained after evisceration; also its low fat content as well as the tasteless and whiteness of its meat make it attractive commercially (Encinas-Arzate et al., 2014). These characteristics are currently being exploited in our region, mainly by the industry dedicated to the exploitation of squid, which is an attractive species for the elaboration of Protein Concentrates (PC). PC can be used for the elaboration of gelled products, where the setting could play a fundamental role in the characteristics and quality of the gel obtained.

In a research carried out by Tachasirinukun et al. (2016) the setting effect from spotted featherback (SF) muscle at 4, 25,40 y $60{ }^{\circ} \mathrm{C}$ at different times was investigated, they found that setting at $25^{\circ} \mathrm{C}$ was the better to prevent proteolysis and hence strengthen the gel of SF muscle. On the other hand, Yongsawatdigul \& Sinsuwan (2007) studied the setting effect on tilapia muscle at 4 and $40^{\circ} \mathrm{C}$ for $30 \mathrm{~min}$, founding that breaking force and deformation of gels increased during setting at $40{ }^{\circ} \mathrm{C}$, attributing this behavior to the formation of higher molecular weight protein, possibly by the actions of transglutaminase endogenous.

In studies carried out by Benjakul et al. (2002) with snapper, corvine, and barracuda, the authors investigated the setting effect at $40{ }^{\circ} \mathrm{C}$ on the textural properties and changes that this phenomenon causes in the myofibrillar proteins during the production of surimi. They found that each species possesses an optimal setting temperature, which can be determined by the heat stability of myosin. On the other hand, it is known that gel quality is not always improved by setting, this quality depending on each species (Numakura et al., 1985). Therefore, it is important to identify whether setting is recommendable for a given species.

At present, several studies have been carried out on the gelation of giant squid (Dosidicus gigas) mantle proteins. However, the effect of the setting on gelation and the textural characteristics of the obtained gels has not, to our knowledge, been studied. Therefore, the present work focused on studying the influence 
of the setting on the thermal gelation of proteins from giant squid mantle and its effect on the physicochemical changes of the proteins and textural characteristics of the gels obtained.

\section{Materials and methods}

\subsection{Raw material}

Giant squid (Dosidicus gigas) were harvested off the coast of Kino Bay, Mexico $\left(27^{\circ} \mathrm{N}\right.$ and $\left.110^{\circ} \mathrm{W}\right)$, in August, 2015. Ten specimens were decapitated and degutted on-site, then washed with fresh water at room temperature $\left(25^{\circ} \mathrm{C}\right)$. The mantles (experimental samples) were bagged, placed in alternating ice-squid-ice layers in a portable cooler, and transported to the laboratory. Time elapsed between capture and their arrival at the laboratory did not exceed $12 \mathrm{~h}$.

\subsection{Generation of protein concentrate (PC)}

The squid mantle was defrosted at $5{ }^{\circ} \mathrm{C}$ over the course of $12 \mathrm{~h}$. It was then chopped into small pieces and homogenized in refrigerated water $\left(4-6^{\circ} \mathrm{C}\right)$ at a proportion of $1: 3$ (mantle: water) using a tissue homogenizer. The mixture was then centrifuged at $16,000 \mathrm{~g} / 15 \mathrm{~min} / 2{ }^{\circ} \mathrm{C}$ in a refrigerated centrifuge (Sorvall Biofugue Stratos, Thermo Scientific, Germany). The supernatant was discarded, and the precipitant was considered the protein concentrate (PC) (Cortés-Ruiz et al., 2008). The PC was packed in polyethylene bags and stored on ice in a refrigerated chamber until use on the same working day.

\subsection{Heat-set gel preparation}

Sols were prepared from the PC by adding $2.5 \% \mathrm{NaCl}$ and adjusting the humidity to $86 \%$. The paste was homogenized at short intervals in a Model DLC-8 Plus Cuisinart Food Processor (Cuisinart Inc., Greenwich, CT). Each sol was packed into a Petri dish $(1 \mathrm{~cm}$ height $)$ and vacuum sealed in moisture/vapor-proof film bags (Cryovac Corp., Duncan, SC) with a Super Vac Smith vacuum machine (Smith Equipment Co., Clifton, NJ). Each sol was heat-set in a water bath at 30 or $60^{\circ} \mathrm{C}$ by 30,60 , and $90 \mathrm{~min}$ (setting), obtaining different systems: $\mathrm{SO}$, control; $\mathrm{S} 1,30^{\circ} \mathrm{C} / 30 \mathrm{~min} ; \mathrm{S} 2,30^{\circ} \mathrm{C} / 60 \mathrm{~min} ; \mathrm{S} 3,30^{\circ} \mathrm{C} / 90 \mathrm{~min}$; $\mathrm{S} 4,60^{\circ} \mathrm{C} / 30 \mathrm{~min} ; \mathrm{S} 5,60^{\circ} \mathrm{C} / 60 \mathrm{~min} ; \mathrm{S} 6,60^{\circ} \mathrm{C} / 90 \mathrm{~min}$. After the setting, gels were prepared heating at $90^{\circ} \mathrm{C} / 30 \mathrm{~min}$ obtaining the following protein systems: G0, G1, G2, G3, G4, G5 and G6. Heat-set gels were immediately chilled to $5-10{ }^{\circ} \mathrm{C}$ in an ice/water mixture and maintained at $2-4{ }^{\circ} \mathrm{C}$ overnight prior to functional evaluation.

\subsection{Protein fractionation}

Sarcoplasmic, myofibrillar, alkali-soluble and stroma proteins were fractionated based on their solubility, following the separation scheme proposed by Hashimoto et al. (1979). Protein concentration in each fraction was determined by the micro-Kjeldahl method (Association of Official Analytical Chemists, 2005).

\subsection{Electrophoretic profile (SDS-PAGE)}

Proteins were analyed by Sodium Dodecyl Sulfate-PolyAcrylamide Electrophoresis (SDS-PAGE) according to the method of Laemmli (1970). SDS-PAGE consisted of 10\% running gel and $5 \%$ stacking gel. Twenty $\mu \mathrm{L}$ of each sample was loaded onto the gels. After separation, the proteins were fixed and stained with Coomassie Blue R-250. The results were expressed in kilodaltons $(\mathrm{kDa})$. Calculations were performed with Quantity One ver. 4.6.9 statistical software. The results were expressed in percentages of protein.

\subsection{Surface hydrophobicity (SoANS)}

Surface hydrophobicity was determined according to the Kato \& Nakai (1980) method with modifications, utilizing ANS (1-Anilline-8-Naftalen-Sulphonate) as probe. The protein was dissolved in phosphate buffer $\left(15.6 \mathrm{mM} \mathrm{Na}_{2} \mathrm{HPO} 4\right.$ and $\left.3.5 \mathrm{mM} \mathrm{KH}_{2} \mathrm{PO} 4\right) \mathrm{pH}$ 7.5 to obtain different concentrations $(12,24,48$, and $80 \mathrm{mg} / \mathrm{mL})$. Then, the diluted protein $(4 \mathrm{~mL})$ was mixed with $80 \mu \mathrm{L}$ of $2 \mathrm{mM}$ ANS in $20 \mathrm{mM}$ Tris-HCl buffer, $\mathrm{pH}$ 7.0. The fluorescence intensity of ANS-protein conjugates was measured using a luminescence spectrophotometer (LS 55; Perkin-Elmer, NJ, USA) utilizing a $1 \%$ attenuator. Excitation and emission wavelengths of 414 and $500 \mathrm{~nm}$, respectively, were used. Surface hydrophobicity was calculated from the initial slope of the plot of fluorescence intensity against the protein concentration and was referred as SoANS.

\subsection{Total sulfhydryls (TSH)}

Total Sulfhydryls (TSH) were determined according to the procedure reported by Patrick \& Swaisgood (1976), with modifications. One $\mathrm{mL}$ of protein solution $0.1 \%$ in phosphate buffer $\left(\mathrm{Na}_{2} \mathrm{HPO}_{4} 15.6 \mathrm{mM}\right.$, and $\left.\mathrm{KH}_{2} \mathrm{PO}_{4} 3.5 \mathrm{mM}\right) \mathrm{pH} 7.4$ was combined with $1 \mathrm{~mL}$ of $10 \mathrm{mM}$ DTNB $(5,5$-dithio-bis 2-nitrobenzoic acid) in $20 \mathrm{mM}$ Tris- $\mathrm{HCl}$ buffer, $\mathrm{pH}$ 7.0. Then, $1.4 \mathrm{~g}$ of urea was added. After incubation at $40^{\circ} \mathrm{C}$ for $25 \mathrm{~min}$, the total volume was adjusted to $4 \mathrm{~mL}$ with the same phosphate buffer. Absorbance at $412 \mathrm{~nm}$ was measured using a spectrophotometer (Cary 50; Varian, Walnut Creek, CA, USA). Total SH content was calculated employing a molar extinction coefficient of $13,600 \mathrm{M}^{-1} \mathrm{~cm}^{-1}$.

\subsection{Gel-Forming Ability (GFA)}

Water holding capacity (WHC)

The WHC was measured using the methodology reported by Jiang et al. (1985). A 5-g portion of each gel was centrifuged in a refrigerated centrifuge at $3000 \mathrm{x} \mathrm{g} / 20 \mathrm{~min} / 4^{\circ} \mathrm{C}$. (Sorvall Biofugue Stratos, Thermo Scientific, Germany). The WHC was expressed as "water retained", which was the sample weight loss percentage with respect to its initial weight.

\section{Texture profile analysis (TPA)}

The gels were tempered for $60 \mathrm{~min}$ at room temperature $\left(25^{\circ} \mathrm{C}\right)$ prior to analysis. The TPA was conducted on cylinder-shaped samples of uniform dimensions ( $1 \mathrm{~cm}$ diameter and $1 \mathrm{~cm}$ height) obtained from each gel using a sharp-edged plastic tube. The texture 
was assessed using a TA-XT2 Plus Texturometer (Food Technology Corp., Sterling, VA) with a $3.8 \mathrm{~cm}$ diameter compression plunge attached to a $100 \mathrm{~N}$ load cell. Compression forces at $75 \%$ of the original gel sample height were used to compute compression hardness, fracture, cohesiveness and elasticity.

\section{Color}

The color of gels was measured by tri-stimulus colorimetry using a chroma meter CR-400 (Konica Minolta Sensing, Inc. Tokyo, Japan). The color coordinates for degree of lightness (L), redness/greenness (+a/-a), and yellowness/blueness (+b/-b) were obtained. The whiteness index (WI) was calculated from the color coordinates as follows: $\mathrm{WI}=\left[100-\left[(100-\mathrm{L})^{2}+\mathrm{a}^{2}+\mathrm{b}^{2}\right]^{1 / 2}\right]$ (Lanier, 1992).

\section{Statistic analysis}

A factorial design with two main effects was used in this experiment. Main effect A was due to 2 temperatures ( 30 and $60^{\circ} \mathrm{C}$ ), and main effect $B$ was due to 3 incubation times (30, 60 and $90 \mathrm{~min})$. When required, Tukey multiple comparisons were performed using a significance level of $95 \%$. The data were analyzed using JMP software version 5.0.1.

\section{Results and discusion}

\subsection{Fractionation of proteins}

The protein fractions obtained from the different systems are presented in Table 1 . The solubility pattern was significantly different $(p<0.05)$ among all systems for all protein fractions $\left(\mathrm{AB}^{\star}<0.05\right)$.

Differences in solubility denote conformational changes in proteins by the effect of treatments. The solubility pattern of the S0 system is the normal pattern of the soles made from squid mantle, that is, a high amount of soluble protein at ionic strength (I) 0.05 , although much soluble protein has already been removed. It has a low soluble-protein content at $I=0.5$ (myofibrillar protein), which is markedly lower than the myofibrillar fraction reported for this species (Cortés-Ruiz et al., 2008). The latter could be due to a high content of soluble protein at $I=0.05$ and its solubility, mainly in alkali. The high content of alkali-soluble protein could be attributed to the use of frozen sample, because it is known that the freeze-thaw process denatures proteins, which can be detected in the alkali-soluble fraction (MurrietaMartínez et al., 2015).

Comparing treatments at 30 and $60^{\circ} \mathrm{C}$, it can be observed that the soluble fraction at $I=0.05$ was lower in the S4, S5, and S6 systems. The same behavior was found in the soluble fraction in $I=0.5$ and alkali-soluble proteins. This can be attributed to the fact that these systems were exposed to a greater thermal treatment, which could have repercussions in protein denaturation. This is confirmed by a significant increase in the content of insoluble protein at any ionic strength and even in alkali solutions. The high content of insoluble protein, in relation to the control, can be attributed to the thermal process $\left(30\right.$ and $\left.60^{\circ} \mathrm{C}\right)$, being higher in protein systems submitted to higher temperatures. It is known that at this temperature, the formation of disulfide bonds, as well as of hydrophobic interactions are favored, at which aggregation is facilitated, being the main chemical interactions that govern the initiation of the gelation phenomenon (Kim et al., 2003).

\subsection{Electrophoretic profile (SDS-PAGE)}

The electrophoretic profile of the proteins from gels is depicted in Figure 1. The S0 system (no setting) shows the main bands that are characteristic of giant squid protein concentrates. No differences were detected between the S0 system and the systems incubated at $30{ }^{\circ} \mathrm{C}(\mathrm{S} 1, \mathrm{~S} 2$, and S3), indicating that

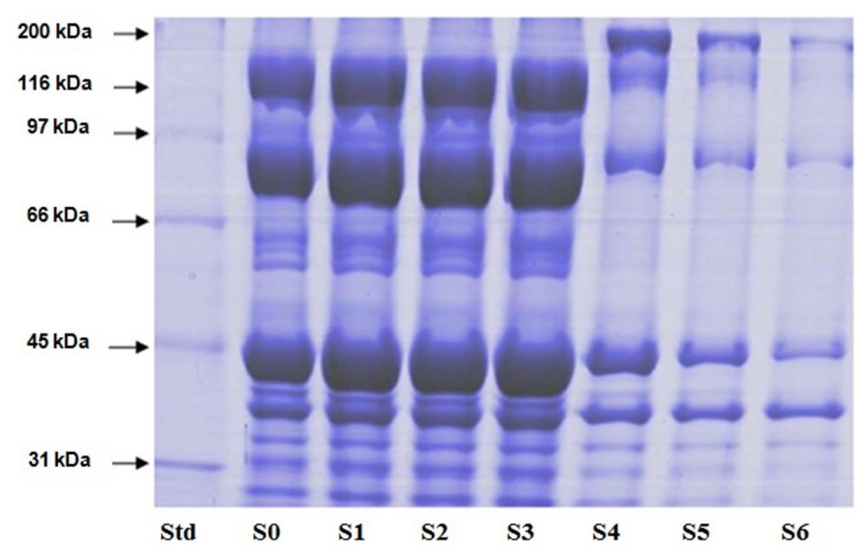

Figure 1. Electrophoretic profile in sols after the setting. S0, control; S1, $30{ }^{\circ} \mathrm{C} / 30 \mathrm{~min} ; \mathrm{S} 2,30^{\circ} \mathrm{C} / 60 \mathrm{~min} ; \mathrm{S} 3,30^{\circ} \mathrm{C} / 90 \mathrm{~min}$; S4, $60{ }^{\circ} \mathrm{C} / 30 \mathrm{~min}$; $\mathrm{S} 5,60^{\circ} \mathrm{C} / 60 \mathrm{~min} ; \mathrm{S} 6,60^{\circ} \mathrm{C} / 90 \mathrm{~min}$.

Table 1. Fractionation of proteins in sols after the setting.

\begin{tabular}{ccccc}
\hline Treatment & Soluble in $I=0.05$ & Soluble in $I=0.5$ & Soluble in alkali & Insoluble \\
\hline S0 & $16.7 \pm 0.0^{\mathrm{a}}$ & $30.0 \pm 0.0^{\mathrm{a}}$ & $21.4 \pm 0.0^{\mathrm{a}}$ & $0.3 \pm 0.0^{\mathrm{a}}$ \\
S1 & $14.6 \pm 0.1^{\mathrm{a}}$ & $26.9 \pm 0.0^{\mathrm{b}}$ & $19.9 \pm 0.0^{\mathrm{b}}$ & $14.4 \pm 0.0^{\mathrm{b}}$ \\
S2 & $14.9 \pm 0.0^{\mathrm{a}}$ & $27.2 \pm 0.1^{\mathrm{b}}$ & $18.2 \pm 0.0^{\mathrm{b}}$ & $15.7 \pm 0.0^{\mathrm{b}}$ \\
S3 & $12.7 \pm 0.0^{\mathrm{b}}$ & $27.2 \pm 0.1^{\mathrm{b}}$ & $18.6 \pm 0.0^{\mathrm{b}}$ & $17.2^{\mathrm{b}} \pm 0.0^{\mathrm{c}}$ \\
S4 & $5.7 \pm 0.2^{\mathrm{c}}$ & $15.7 \pm 0.0^{\mathrm{c}}$ & $12.1 \pm 0.0^{\mathrm{c}}$ & $36.3 \pm 0.0^{\mathrm{d}}$ \\
S5 & $3.2 \pm 0.2^{\mathrm{d}}$ & $14.3 \pm 0.0^{\mathrm{c}}$ & $12.2 \pm 0.0^{\mathrm{c}}$ & $43.2 \pm 0.0^{\mathrm{e}}$ \\
S6 & $2.8 \pm 0.1^{\mathrm{e}}$ & $14.2 \pm 0.0^{\mathrm{c}}$ & $43.3 \pm 0.0^{\mathrm{e}}$ \\
\hline
\end{tabular}

The data are the mean $\pm \operatorname{std}$ of $\mathrm{n}=3$. Different superscripts in each column indicate significant differences $(\mathrm{p}<0.05)$. S0, control; $\mathrm{S} 1,30^{\circ} \mathrm{C} / 30 \mathrm{~min} ; \mathrm{S} 2,30^{\circ} \mathrm{C} / 60 \mathrm{~min} ; \mathrm{S} 3,30^{\circ} \mathrm{C} / 90 \mathrm{~min}$; $\mathrm{S} 4,60^{\circ} \mathrm{C} / 30 \mathrm{~min} ; \mathrm{S} 5,60^{\circ} \mathrm{C} / 60 \mathrm{~min} ; \mathrm{S} 6,60^{\circ} \mathrm{C} / 90 \mathrm{~min}$. 
the denaturation detected in the fractionation patterns does not lead to the formation of covalent aggregates. It can also be appreciated that incubation time did not exert a noticeable effect on the banding pattern. This demonstrates the little endogenous proteolytic activity or lack of same in the protein concentrate, which could be due to the fact that these enzymes were discarded during obtention of the protein concentrate.

On the other hand, as in protein fractionation, sharp differences were found when comparing the treatments submitted to $30{ }^{\circ} \mathrm{C}$ with those submitted to $60{ }^{\circ} \mathrm{C}(\mathrm{S} 4, \mathrm{~S} 5$, and S6). In these, the possible aggregation of myosin heavy chains with light meromyosin was observed, due to the appearance of bands $>200 \mathrm{kDa}$ and the disappearance of bands of approximately $70 \mathrm{kDa}$. It is possible that the formation of these aggregates was due to covalent interactions, that is, by means of the formation of disulfide bridges, since sample treatment with SDS solely breaks down electrostatic and Van der Waals interactions, but not disulfide bridges. In studies carried out with bigeye snapper and barracuda, it has been pointed out that, during a prolonged setting, the myosin heavy chain decreases markedly compared with systems that had no setting, this being attributed to protein crosslinking during prolonged treatment (Benjakul et al., 2002).

\subsection{Surface hydrophobicity (SoANS)}

The surface hydrophobicity detected in the different systems is shown in Figure 2. For this study, the S4, S5, and $\mathrm{S} 6\left(60^{\circ} \mathrm{C}\right)$ systems were omitted because much of the protein had already formed gel and it could not be homogenized in aqueous medium. The systems presented hydrophobicity values in descending order $(p<0.05)$, being higher in S0 than in S3, which could be due to a greater solubility of the S0 system, as can be observed in the protein fractionation.

This allows more molecules of the ANS reagent to interact with hydrophobic regions of the proteins. An increase in hydrophobicity is usually indicative of protein unfolding; when this occurs, the proteins expose a greater proportion of hydrophobic amino acids that, in their native state, tend to be located toward the interior of the molecule. Such unfolding may favor the hydrophobic interactions between the proteins, thus affecting the solubility patterns, as can be noted in Table 1 .

\subsection{Total sulfhydryls (TSH)}

A decrease $\left(\mathrm{AB}^{*}<0.05\right)$ in TSH content was found (Table 2). No significant differences were found between the S0 and the systems incubated at $30^{\circ} \mathrm{C}(\mathrm{S} 1, \mathrm{~S} 2$, and S3), indicating that protein unfolding associated with temperature and incubation time was not sufficient to induce the formation of disulfide bridges. This could be because a higher temperature is required to favor the formation of SS bonds, since this has been reported to start in the temperature range between 50 and $55^{\circ} \mathrm{C}$ and sometimes to contribute to the strength and stability of the gel (Yongsawatdigul \& Park, 1996).
Protein systems incubated at $60^{\circ} \mathrm{C}$ demonstrated a significant decrease $(p<0.05)$ compared with protein systems incubated at $30{ }^{\circ} \mathrm{C}$. This decrease may be due to the formation of the SS bond, because there are favorable conditions for this reaction. The previous assumption may be based on the electrophoretic profile, in which protein aggregation was observed in systems incubated at $60^{\circ} \mathrm{C}$. It can also be observed that, even though it is not significant $(p \geq 0.05)$, the decrease in TSH becomes more evident as incubation time increases, which could be due to a longer time required for the interconversion of SH by SS.

\subsection{Color}

As can be seen in Table 3, significant differences $\left(\mathrm{AB}^{*}<0.05\right)$ were found for $\mathrm{L}^{*}$ values (Luminosity), exhibiting greater clarity in the G6 system. Similar behavior was found for the whiteness index $(p<0.05)$ where, again, G6 was the system that demonstrated the highest values. In addition, the high whiteness-index values in all treatments can be attributed to the high $\mathrm{L}^{*}$ values, but also to the low $\mathrm{a}^{*}$ and $\mathrm{b}^{*}$ values. Therefore, it can be stated that the use of the setting favorably affects the color parameters, mainly the brightness and whiteness index, which is one of the most important indicators in that a white coloration is desirable in this type of products. Significant differences $\left(\mathrm{AB}^{*}<0.05\right)$ were found in the $\mathrm{b}^{*}$ values (yellowi-blue), indicating that a slightly yellowish coloration was presented for gels with a setting at $60^{\circ} \mathrm{C}$.

This could be attributed to the fact that G4, G5, and G6 underwent more aggressive heating compared with the remainder of the treatments.

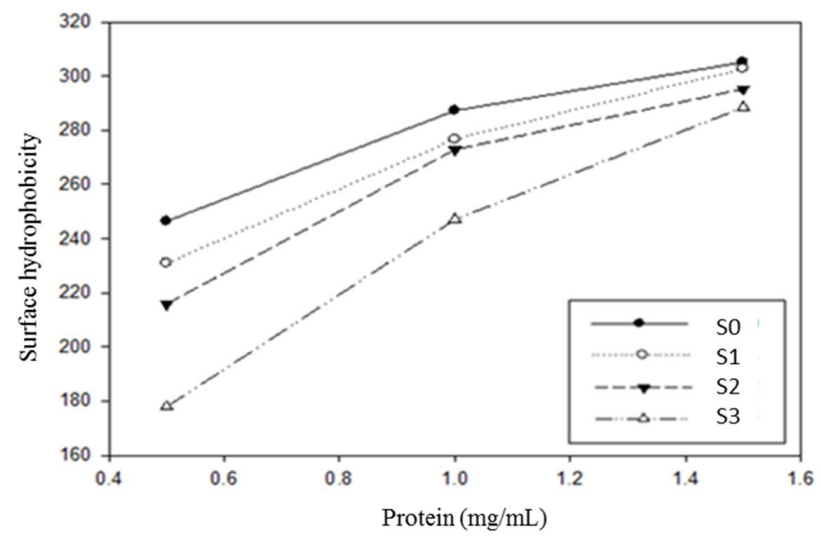

Figure 2. Surface hydrophobicity in sols after the setting. S0, control; $\mathrm{S} 1,30^{\circ} \mathrm{C} / 30 \mathrm{~min} ; \mathrm{S} 2,30^{\circ} \mathrm{C} / 60 \mathrm{~min} ; \mathrm{S} 3,30^{\circ} \mathrm{C} / 90 \mathrm{~min}$.

Table 2. Total Sulfhydryls in sols after the setting.

\begin{tabular}{|c|c|c|c|c|c|c|}
\hline \multicolumn{7}{|c|}{$\begin{array}{l}\text { Protein system } \\
\left(\text { moles } \times 10^{5} \mathrm{~g}\right)\end{array}$} \\
\hline So & $\mathrm{S} 1$ & $\mathrm{~S} 2$ & S3 & $\mathrm{S} 4$ & S5 & S6 \\
\hline $5.1 \pm 0.1^{\mathrm{a}}$ & $5.4 \pm 0.1^{\mathrm{a}}$ & $5.5 \pm 0.0^{\mathrm{a}}$ & $5.4 \pm 0.0^{\mathrm{a}}$ & $4.6 \pm 0.5^{b}$ & $4.6 \pm 0.1^{b}$ & $4.2 \pm 0.0^{b}$ \\
\hline
\end{tabular}


Table 3. Setting effect on the color of gels.

\begin{tabular}{ccccc}
\hline Treatment & $\mathrm{L}^{*}$ & $\mathrm{a}^{*}$ & $\mathrm{~b}^{*}$ & Whiteness index \\
\hline G0 & $84.2 \pm 0.7^{\mathrm{a}}$ & $-2.6 \pm 0.0^{\mathrm{a}}$ & $3.3 \pm 0.2^{\mathrm{a}}$ & $83.7 \pm 0.8^{\mathrm{a}}$ \\
G1 & $84.4 \pm 0.1^{\mathrm{a}}$ & $-2.2 \pm 0.0^{\mathrm{a}}$ & $4.9 \pm 0.1^{\mathrm{b}}$ & $83.5 \pm 0.1^{\mathrm{a}}$ \\
G2 & $84.3 \pm 0.2^{\mathrm{a}}$ & $-2.2 \pm 0.1^{\mathrm{a}}$ & $4.8 \pm 0.1^{\mathrm{b}}$ & $83.4 \pm 0.2^{\mathrm{a}}$ \\
G3 & $87.3 \pm 0.0^{\mathrm{b}}$ & $-2.1 \pm 0.0^{\mathrm{a}}$ & $4.6 \pm 0.1^{\mathrm{b}}$ & $86.3 \pm 0.0^{\mathrm{a}}$ \\
G4 & $90.3 \pm 0.5^{\mathrm{c}}$ & $-2.1 \pm 0.0^{\mathrm{a}}$ & $5.6 \pm 0.0^{\mathrm{c}}$ & $88.4 \pm 0.0^{\mathrm{ab}}$ \\
G5 & $89.2 \pm 0.0^{\mathrm{c}}$ & $-2.1 \pm 0.0^{\mathrm{ab}}$ & $6.2 \pm 0.2^{\mathrm{c}}$ & $87.7 \pm 0.0^{\mathrm{b}}$ \\
G6 & $91.6 \pm 0.1^{\mathrm{d}}$ & $-2.0 \pm 0.0^{\mathrm{b}}$ & $89.3 \pm 0.0^{\mathrm{a}}$ \\
\hline
\end{tabular}

The data are the mean $\pm \operatorname{std}$ of $\mathrm{n}=3$. Different superscripts in each column indicate significant differences (p $<0.05)$. G0 (Control): $90{ }^{\circ} \mathrm{C} / 30 \mathrm{~min}$. G1: $30^{\circ} \mathrm{C} / 30 \mathrm{~min}$. G2: $30^{\circ} \mathrm{C} / 60 \mathrm{~min}$. G3: $30^{\circ} \mathrm{C} / 90 \mathrm{~min}$. G4: $60^{\circ} \mathrm{C} / 30 \mathrm{~min}$. G5: $60^{\circ} \mathrm{C} / 60 \mathrm{~min}$. G6: $60^{\circ} \mathrm{C} / 90 \mathrm{~min}$. After setting all treatments were heated to $90^{\circ} \mathrm{C}$ for $30 \mathrm{~min}$.

Table 4. Setting effect on water holding capacity and texture profile analysis of gels.

\begin{tabular}{ccccc}
\hline Treatment & WHC $(\%)$ & Hardness $(\mathrm{N})$ & Cohesiveness & Elasticity \\
\hline G0 & $76.7 \pm 0.1^{\mathrm{a}}$ & $735 \pm 65^{\mathrm{a}}$ & $0.5 \pm 0.1^{\mathrm{a}}$ & $0.9 \pm 0.0^{\mathrm{a}}$ \\
G1 & $75.0 \pm 2.0^{\mathrm{a}}$ & $350 \pm 41^{\mathrm{b}}$ & $0.2 \pm 0.0^{\mathrm{b}}$ & $0.6 \pm 0.0^{\mathrm{bc}}$ \\
G2 & $76.0 \pm 3.0^{\mathrm{a}}$ & $328 \pm 13^{\mathrm{bc}}$ & $0.3 \pm 0.0^{\mathrm{b}}$ & $0.8 \pm 0.0^{\mathrm{a}}$ \\
G3 & $76.4 \pm 5.0^{\mathrm{a}}$ & $315 \pm 12^{\mathrm{bc}}$ & $0.2 \pm 0.0^{\mathrm{b}}$ & $0.6 \pm 0.0^{\mathrm{b}}$ \\
G4 & $76.1 \pm 0.5^{\mathrm{a}}$ & $264 \pm 28^{\mathrm{bc}}$ & $0.2 \pm 0.0^{\mathrm{b}}$ & $0.5 \pm 0.0^{\mathrm{c}}$ \\
G5 & $76.0 \pm 3.0^{\mathrm{a}}$ & $221 \pm 7^{\mathrm{cd}}$ & $0.0^{\mathrm{b}}$ & $0.5 \pm 0.1^{\mathrm{c}}$ \\
G6 & $68.7 \pm 0.1^{\mathrm{a}}$ & $127 \pm 3^{\mathrm{d}}$ & $0.0^{\mathrm{b}}$ & $0.5 \pm 0.0^{\mathrm{c}}$ \\
\hline
\end{tabular}

The data are the mean \pm std of $\mathrm{n}=3$. Different superscripts in each column indicate significant differences ( $\mathrm{p}<0.05)$. G0 (Control): $90{ }^{\circ} \mathrm{C} / 30 \mathrm{~min}$. G1: $30{ }^{\circ} \mathrm{C} / 30 \mathrm{~min}$. G2: $30^{\circ} \mathrm{C} / 60 \mathrm{~min}$. G3: $30{ }^{\circ} \mathrm{C} / 90 \mathrm{~min}$. G4: $60{ }^{\circ} \mathrm{C} / 30 \mathrm{~min}$. G5: $60{ }^{\circ} \mathrm{C} / 60 \mathrm{~min}$. G6: $60{ }^{\circ} \mathrm{C} / 90 \mathrm{~min}$.

\subsection{Water holding capacity (WHC)}

Table 4 illustrates the WHC results, where no significant difference $(p \geq 0.05)$ was found. The WHC between the different gels ranged between $68.7 \pm 0.1$ and $76.7 \pm 0.1 \%$. These values are in agreement with the reported range for giant squid mantle and its respective neutral protein concentrate (64.6 and $81.5 \%$ ) (Cortés-Ruiz et al., 2008). The WHC values obtained may be due to the protein-water interaction that, in this study, were not affected by the setting application.

\subsection{Texture profile analysis (APT)}

Hardness (Table 4) exhibited a significant difference $\left(\mathrm{AB}^{\star}<0.05\right)$. A stronger gel was formed when the PC was heated to $90{ }^{\circ} \mathrm{C}$ without prior setting (control), while for the remaining gels, hardness values presented in descending order, from the G1 to the G6 system, indicating that both temperature and time exerted a significant effect on gel hardness. Similar behavior was found for cohesiveness and elasticity parameters $\left(\mathrm{AB}^{*}<0.05\right)$, where $\mathrm{G} 0$ demonstrated values of $0.5 \pm 0.1$ and $0.9 \pm 0.0$ for cohesiveness and elasticity, respectively. These values indicate that more work was required to break the molecular interactions of the system, which was reflected in the hardness values. The latter indicates that, unlike other species, the setting in the protein gelation of giant squid mantle (Dosidicus gigas) is not recommended. This could be attributed to the little or no activity of endogenous transaminase from squid mantle muscle. On the other hand, the reason that setting treatments showed lower gelling ability could be attributed to protein aggregation, as demonstrated by the results of protein fractionation and electrophoresis, resulting in a less ordered protein network after raising the temperature to $90{ }^{\circ} \mathrm{C}$.

\section{Conclusion}

Under the conditions of this study, the setting at 30 or $60^{\circ} \mathrm{C}$ did not have a favorable effect on the quality of the gel elaborated from giant squid mantle. Gels made with a setting of $30^{\circ} \mathrm{C}$ showed a better quality compared with gels with a $60^{\circ} \mathrm{C}$ setting, because the setting at $60^{\circ} \mathrm{C}$ demonstrated to lead to protein aggregation at the different times employed, impeding improvement of the gel characteristics. This suggests that setting as pretreatment does not comprise a good alternative for the gelation of giant squid mantle proteins, because the control treatment (no setting) was that which exhibited better textural characteristics.

\section{References}

Association of Official Analytical Chemists - AOAC. (2005). Association of official analytical chemist official methods of analysis of association of official analytical chemist (18th ed.). Arlington: AOAC.

Benjakul, S., Visessanguan, W., \& Chantarasuwan, C. (2002). Effect of high-temperature setting on gelling characteristic of surimi from some tropical fish. Food Chemistry, 82(4), 567-574. http://dx.doi. org/10.1016/S0308-8146(03)00012-8.

Cortés-Ruiz, J. A., Pacheco-Aguilar, R., Elena Lugo-Sánchez, M., Gisela Carvallo-Ruiz, M., \& García-Sánchez, G. (2008). Production and functional evaluation of a protein concentrate from giant squid (Dosidicus gigas) by acid dissolution and isoelectric precipitation. Food Chemistry, 110(2), 486-492. http://dx.doi.org/10.1016/j. foodchem.2008.02.030. PMid:26049243.

Encinas-Arzate, J. J., Ezquerra-Brauer, J. M., Ocaño-Higuera, V. M., Ramirez-Wong, B., Armenta-Villegas, L., Torres-Arreaola, W., \& Marquez-Rios, E. (2014). Effect of ionic strength on soluble protein removal from giant squid mantle (Dosidicus gigas) and functional evaluation of protein recovery. Food Science and Biotechnology, 23(2), 401-407. http://dx.doi.org/10.1007/s10068-014-0055-y. 
Hashimoto, K., Watabe, S., Kono, M., \& Shiro, K. (1979). Muscle protein composition of sardine and mackerel. Bulletin of the japanese society of scientific fisheries. Nippon Suisan Gakkaishi, 4(11), 1435-1441. http://dx.doi.org/10.2331/suisan.45.1435.

Jiang, S., Ho, M., \& Lee, T. C. (1985). Optimization of the freezing conditions on mackerel and amberfish for manufacturing minced fish. Journal of Food Science, 50(3), 727-732. http://dx.doi. org/10.1111/j.1365-2621.1985.tb13783.x.

Kato, A., \& Nakai, S. (1980). Hydrophobicity determined by a fluorescence probe method and its correlation with surface properties of proteins. Biochimica et Biophysica Acta, 624(1), 13-20. http://dx.doi. org/10.1016/0005-2795(80)90220-2. PMid:7407231.

Kim, Y. S., Park, J. W., \& Choi, Y. J. (2003). New approaches for the effective recovery of fish proteins and their physicochemical characteristics. Fisheries Science, 69(6), 1231-1239. http://dx.doi. org/10.1111/j.0919-9268.2003.00750.x.

Laemmli, U. K. (1970). Cleavage of structural proteins during the assembly of the head of bacteriophage T4. Nature, 227(5259), 680685. http://dx.doi.org/10.1038/227680a0. PMid:5432063.

Lanier, T. C. (1992). Surimi manufacturing from whitefish. In T. C. Lanier and C.M. Lee (Eds.), Surimi Technology (pp. 123-163). New York: Marcel Dekker.

Murrieta-Martínez, C. L., Ezquerra-Brauer, J. M., Ocaño-Higuera, V. M., Cinco-Moroyoqui, F. J., Torres-Arreola, W., \& Márquez-Ríos, E. (2015). Aislamiento y Caracterización Parcial de Miosina de Manto de Calamar Gigante (Dosidicus gigas). CYTA: Journal of Food, 13(3), 392-399. http://dx.doi.org/10.1080/19476337.2014.988183.

Nigmatullin, C. M., Nesis, K. N., \& Arkhipkin, A. I. (2008). A review of the biology of the jumbo squid Dosidicus gigas (Cephalopoda: Ommastrephidae). Fisheries Research, 54(1), 9-19. http://dx.doi. org/10.1016/S0165-7836(01)00371-X.

Numakura, T., Seki, N., Kimura, I., Toyoda, K., Fujita, T., Takama, K., \& Arai, K. (1985). Cross-linking reaction of myosin in the fish paste during setting (suwari). Nippon Suisan Gakkaishi, 51(9), 1559-1565. http://dx.doi.org/10.2331/suisan.51.1559.

Patrick, P. S., \& Swaisgood, H. E. (1976). Sulfhydryl and disulfide groups in skim milk as affected by direct ultra-high-temperatures heating and subsequent storage. Journal of Dairy Science, 59(4), 594-600. http://dx.doi.org/10.3168/jds.S0022-0302(76)84246-4.

Tachasirinukun, P., Chaijan, M., \& Riebroy, S. (2016). Effect of setting conditions on proteolysis and gelling properties of spotted featherback (Chitala ornata) muscle. Lebensmittel-Wissenschaft + Technologie, 66, 318-323. http://dx.doi.org/10.1016/j.lwt.2015.10.050.

Yongsawatdigul, J., \& Park, J. W. (1996). Linear heating rate affects gelation of Alaska pollock and Pacific whiting surimi. Journal of Food Science, 61, 149-153.

Yongsawatdigul, J., \& Sinsuwan, S. (2007). Aggregation and conformational changes of tilapia actomyosin as affected by calcium ion during setting. Food Hydrocolloids, 21(3), 359-367. http://dx.doi.org/10.1016/j. foodhyd.2006.04.006. 